\title{
The effects of land use at different spatial scales on instream features in agricultural streams
}

\author{
Mariana C. Molina*, Camilo A. Roa-Fuentes, Jaquelini O. Zeni, Lilian Casatti \\ UNESP - Universidade Estadual Paulista, Laboratório de Ictiologia, Departamento de Zoologia e Botânica, IBILCE, Rua Cristóvão Colombo, 2265, 15054-000, São José do \\ Rio Preto, SP, Brazil
}

\section{A R T I C L E I N F O}

\section{Keywords:}

Native forest

Pasture

Sugarcane

Agriculture and Stream homogenization

\begin{abstract}
A B S T R A C T
The conversion of forests into agriculture has been identified as a key process for stream homogenization. However, the effects of this conversion can be scale-dependent. In this context, our aim was to identify the influence of different land uses at different spatial scales (catchment, drainage network and local) on instream features in agricultural streams. We defined six classes of land use: native forest, reforestation, herbaceous and shrubs, pasture, sugarcane and other categories. We obtained 22 variables related to instream, riparian area, stream morphology and water physicochemical characteristics in 86 stream reaches. To identify and isolate the effect of different land uses at different spatial scales on instream features, we performed a partial redundancy analysis (p-RDA). Different land uses and scales influenced instream features and defined two stream groups: (i) homogeneous streams with a higher proportion of sand substrate and instream grasses that were associated with the proportion of herbaceous vegetation at the local scale and with pasture at all scales and (ii) heterogeneous streams with a higher physical habitat integrity associated with the proportion of forest and sugarcane at the local and catchment scales. Land use at the catchment scale affected the physicochemical water properties and stream morphology, whereas stream physical habitat (i.e., substrate, instream cover, marginal vegetation and stream physical habitat condition) was mainly influenced by land use at the local scale (i.e., $150 \mathrm{~m}$ radius). Pure catchment, drainage network and local land uses explained $9 \%, 7 \%$ and $4 \%$, respectively, of the total variation of instream features. Thus, to be most effective, stream conservation and restoration efforts should not be limited to only one scale.
\end{abstract}

\section{Introduction}

Streams are open systems with a strong relationship with their terrestrial surroundings (Hynes, 1975; Allan, 2004). For this reason, the replacement of native forests by agriculture has been identified as a key driver to stream degradation (Wang et al., 1997; Clapcott et al., 2012). Agricultural practices (e.g., soil tillage and the use of pesticides) affect terrestrial-aquatic interactions by increasing siltation, deteriorating water quality, and diminishing allochthonous input such as wood debris (Allan, 2004; Paula et al., 2013). However, streams can be affected differently by these agricultural practices, depending on the spatial scales (Fausch et al., 2002; Feld, 2013; Dala-Corte et al., 2016). For example, shading may be mostly influenced by local canopy, whereas the loading of allochthonous materials is influenced by local and distant upstream segments (Strayer et al., 2003; Paula et al., 2011, 2013).

In addition to the spatial scale, the main land use in each scale (local, riparian zone and catchment) in agroecosystems can determine the stream water quality and physicochemical features (Rasmussen et al., 2011; Paula et al., 2013; Bu et al., 2014; Mori et al., 2015). For instance, the total dissolved phosphate can be positively related to the proportion of pasture in the catchment (Mori et al., 2015). In contrast, the nitrate concentrations can be positively correlated to the proportion of sugarcane at both catchment and riparian scales (Mori et al., 2015) due to the burning of sugarcane biomass (Martinelli and Filoso, 2008; Mori et al., 2015). In addition, Bu et al. (2014) found that forest proportion in the catchment was positively and negatively correlated with the $\mathrm{pH}$ and total nitrogen concentration, respectively. Moreover, Paula et al. (2013) found that the proportion of forest in the catchment was positively correlated to large wood abundance in streams channels. Based on the above information, we can say that the comprehension and prediction of the effects of different land uses at multiple scales on instream features are complex and represent one of the highest challenges for stream ecologists (Strayer et al., 2003; Feld, 2013).

Currently, stream conservation and restoration efforts are concentrated mostly at riparian forest since the presence of a forested riparian buffer can mediate the energetic terrestrial-aquatic interactions,

\footnotetext{
* Corresponding author.

E-mail address: marimolina54@gmail.com (M.C. Molina).
} 
promote channel stability and physical habitat heterogeneity, and reduce inorganic sediment input (Pusey and Arthington, 2003; Sweeney and Newbold, 2014). For this reason, in highly modified catchments, the presence and quality of riparian forest can help mitigate the consequences of agricultural practices. In this context, spatial scaling or multi-scale analysis can help identify areas and physical processes that affect stream ecosystems and, consequently, suggest where and how land management or restoration are more likely to influence these ecosystems to conserve aquatic biota and ecological functions (Burnett et al., 2006; Sheldon et al., 2012; Feld, 2013). Despite the great importance of scale-related influences, studies evaluating land use effects on instream features at multiple scales are rare in the Neotropical region (but see Mori et al., 2015; Leal et al., 2016), probably due to the difficulties associated with the acquisition and processing of the landscape metrics in the SIG software.

Thus, our aim was to identify the influence of different land use at the catchment (i.e., land use in the entire catchment area), drainage network (i.e., land use within $30 \mathrm{~m}$ buffer zone at each streamside) and local radius (i.e., land use in a $150 \mathrm{~m}$ radius circle centered on the georeferenced sampling site) scales on instream reach features in a Neotropical agroecosystem landscape. We expected that different spatial scales (catchment, drainage and local radius) would predict instream environmental characteristics but that the effects could vary across instream variables due to different acting mechanisms (Strayer et al., 2003; Mori et al., 2015; Leal et al., 2016).

\section{Material and methods}

\subsection{Study area}

We worked in two different river basins, Turvo-Grande and São José dos Dourados, located in the northwest of São Paulo State, Brazil (Fig. 1). This region belongs to the Serra Geral geological unit, with basaltic and sedimentary rocks from the Bauru and Cauiá groups (IPT, 1999). According to Silva et al. (2007), soil presents high erosive potential, consisting mainly of unconsolidated substrates, such as sand and clay. Climate is tropical and hot, with two defined seasons: a dry period between June and September, with milder temperatures and lower rainfall, and a wet period, with higher rainfall and temperatures between December and February (IPT, 1999). Agriculture in this region is not recent, and landscape here has been historically fragmented since the beginning of the last century (1900) with the development of agricultural crops, such as coffee, livestock grazing, and more recently sugarcane (Silva et al., 2007). Originally, the region was covered by Semi-deciduous Seasonal Forest (a sub type of Atlantic Forest) with patches of Savannah ("Cerrado"), but currently, native vegetation is less than $4 \%$ of the original area and is restricted to small and unconnected fragments (Silva et al., 2007; Nalon et al., 2008).

\subsection{Site selection and land use characterization}

We conducted a pre-selection of catchments with areas between 400 and 1400 ha (first- to third-order streams according to the Strahler system). From this, 171 different catchments were filtered and recognized during the fieldwork. Due to accessibility and owners' consent, we sampled 86 streams reaches from independent catchments in the above-mentioned region. We classified the land use in each catchment by using orthorectified aerial photographs ('orthophotos') with a 1-m spatial resolution (years 2010/2011). Overall, we defined six landuse classes: (i) native forest, (ii) herbaceous and shrub vegetation, (iii) reforestation, (iv) pasture, (v) sugarcane, and (vi) other categories of land use (Table 1).

For the digital preparation, processing and classification of the orthophotos, we used the ERDAS IMAGINE 9.2 and ArcGis 9.3 softwares. We used a digital elevation model (DEM) with the SWAT extension (Soil and Water Assessment Tool; SWAT, 2009) for ArcGis 9.3 to delineate catchments boundaries. DEM was obtained from ASTER Global Digital Elevation Model project (ASTER GDEM). We obtained the orthophotos from Empresa Paulista de Planejamento Metropolitano SA - EMPLASA $\left(\mathrm{CLUN}^{\circ}\right.$ 060/14). We also used the CANASAT project (sugarcane crop monitoring in Brazil; Rudorff et al., 2010) to identify and quantify the sugarcane areas in São Paulo State for 2012.

\subsection{Definition of explanatory variables}

We evaluated the effects of land use on instream physical habitat on three spatial scales based on Strayer et al. (2003): (i) catchment, which included land use in the entire catchment area; (ii) drainage network, which comprised land use within 60-m buffer zones at the streamsides, with $30 \mathrm{~m}$ on each side of the stream (the width usually established by the current Brazilian Forest Code for streams less than $10 \mathrm{~m}$ wide); and (iii) local radius, which included land use in a circle (150 $\mathrm{m}$ radius) centered on the georeferenced sampling site (adapted from Strayer et al., 2003) (Fig. 2). In addition, to separate the land-use effects on

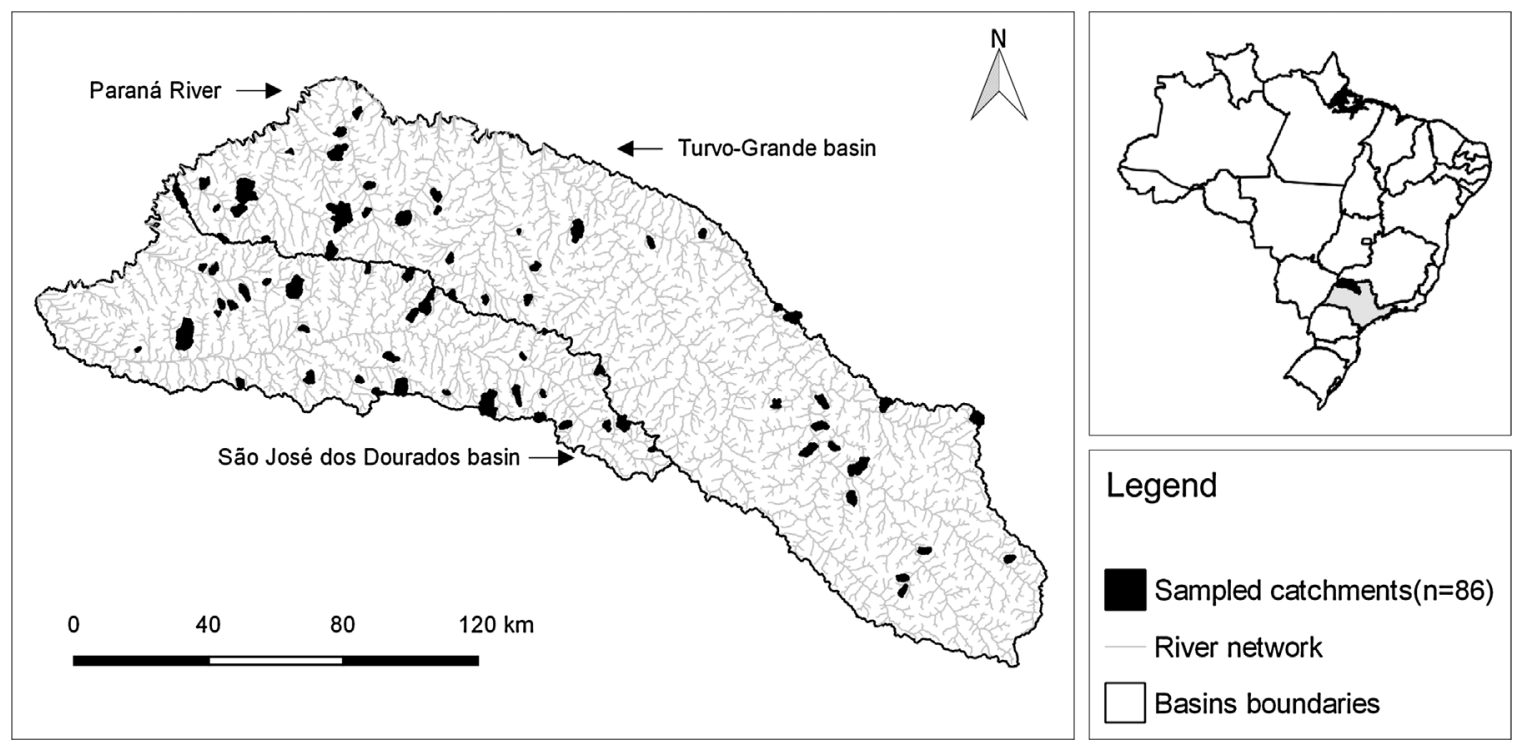

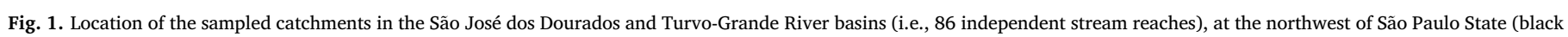
area in the country map), Brazil. Because some catchments are neighbors, they are indistinguishable on the map. 
Table 1

Description of land-use classes identified through orthorectified aerial photographs (years 2010/2011).

\begin{tabular}{|c|c|}
\hline Land-use class & Description \\
\hline Native forest & Areas with native forest (i.e., Savanna and Semi-deciduous seasonal forest). \\
\hline Herbaceous and shrub vegetation & Areas occupied by herbaceous and shrubs, besides species of cattail (Typha spp.). \\
\hline Reforestation & Areas that included planted forests and restored areas (i.e., Eucalyptus spp., Pinus spp. or Hevea spp.). \\
\hline Pasture & Areas used for intensive and extensive livestock, it also included few areas with native grasses (small proportion). \\
\hline Sugarcane & Areas with sugarcane crops (Saccharum spp.) or that showed evidence of being used by sugarcane industry. \\
\hline Other categories & $\begin{array}{l}\text { Areas of different land uses, such as perennial and annual plants for agricultural purposes (Citrus spp., Coffea spp., Zea mays, Sorghum bicolor), } \\
\text { urban area, exposed soil, highways, rural installation, among others }\end{array}$ \\
\hline
\end{tabular}

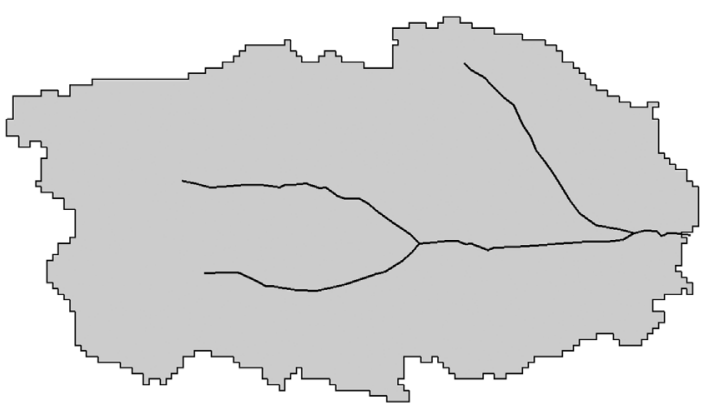

A

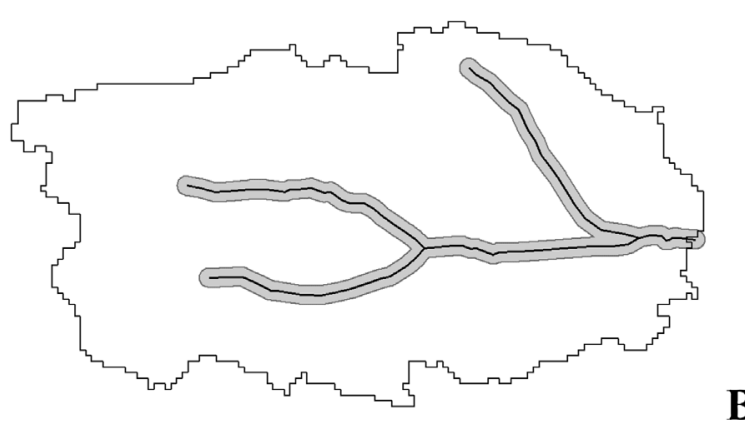

B

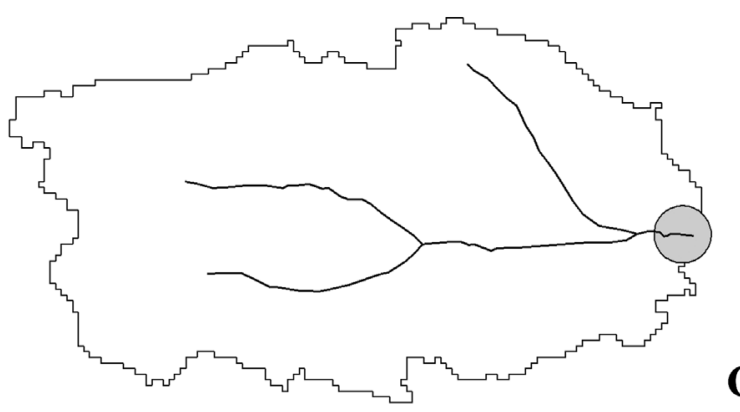

C

Catchment boundary — River network

Fig. 2. Hypothetical catchment with the different spatial scales at which land use was assessed: (A) catchment, (B) drainage network (30 m on each side of the stream), and (C) local radius $(150 \mathrm{~m})$. Spatial scales adapted from Strayer et al., 2003.

instream features from the natural landscape variables, we considered the catchment area, the average slope of the catchment, the altitude and the stream order (Strahler's method; Wang et al., 2003; Leal et al., 2016). Overall, we obtained 22 explanatory variables, six for each scale (catchment, drainage network and local) plus four natural landscape variables (Table 2).

\subsection{Response variables}

We measured 26 stream reach variables related to substrate composition, instream cover, marginal and riparian cover, mesohabitat, physical habitat condition, stream morphology and, physicochemical water characteristics (Table 2). For the substrate composition, we visually estimated at four points along the stream reach the proportion of sand, unconsolidated (clay and silt) and consolidated (gravel, rock, boulder and bedrock) material. For the instream cover, we visually estimated the proportion of the stream bottom occupied by leaf litter and large and small wood debris. Regarding the marginal area, we visually estimated the proportion of stream bank occupied by marginal grasses (mostly the non-native weed Brachiaria spp.), Bryophytes and Pteridophytes, fine roots, large roots, shrubs and exposed stream bank. We also visually estimated the proportion of different mesohabitats (i.e., pool, run and riffles). Moreover, based on a visual quantification of the proportion of mesohabitat, the substrate composition, channel modification, and stream bank structure, we assigned for each stream reach a value of the Physical Habitat Index (PHI, adapted for the study area by Casatti et al., 2006). Stream reaches with high PHI scores show a more heterogeneous channel and are usually associated with high proportions of forest in the catchment, whereas low scores indicate stream reaches with high degrees of habitat homogenization and are associated with agroecosystems (Casatti et al., 2006).

For the width, depth and water velocity variables (i.e., mean), we made three transects (upstream, downstream and in the middle) in each stream reaches, and the measures were taken in these transects. For the mean and standard deviation of the width, we took one measure in each transect (three in total). For the mean and standard deviation of the depth, we took five measures in each transect (15 in total). In addition, we used a flowmeter (Swoffer model 3000) to take three measures in each transect (nine in total) and obtain the water velocity mean and standard deviation. Finally, we used a multiparameter probe (YSI 556 MPS Yellow Springs model) to obtain in situ conductivity, $\mathrm{pH}$, total dissolved solids and water temperature (Table 2). The collection of the visually estimated variables was conducted by the same person in all 86 stream reaches and followed the protocol developed by Casatti et al. (2006).

\subsection{Data analysis}

To identify the correlation between land use at the catchment, drainage network and local spatial scales, we calculated the Pearson correlation coefficient ( $r$ ).

To identify relationships among instream variables, land use at different spatial scales and natural landscape variables, we conducted a redundancy analysis (RDA; Legendre et al., 2011). In the RDA, a matrix of explanatory variables (i.e., land-use classes and natural landscape variables) is used to explain the variation in response variables (i.e., instream variables) (Legendre et al., 2011). We performed a variance inflation factor (VIF; Neter et al., 1996) prior to the RDA to reduce the collinearity among our explanatory variables. Different cut-off values have been suggested for identifying highly collinear variables; in this study, we removed those variables using a VIF $>10$ (Neter et al., 1996). For this reason, we removed forest and herbaceous and shrubs vegetation at the drainage network (VIF $>10$ ) from our forward analysis. Because RDA is a linear model based on linear regressions, we applied data transformations before the analysis to linearize the relationships, to make the frequencies of distributions as symmetrical as 
Table 2

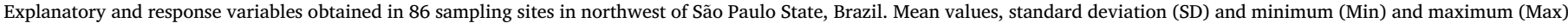
values, along with the code used in the further analysis are provided for each variable.

\begin{tabular}{|c|c|c|c|c|c|c|c|}
\hline Category & Explanatory Variables & Unit & Mean & $\pm \mathrm{SD}$ & Min & Max & Code \\
\hline \multirow[t]{6}{*}{ Catchment scale } & Native forest in the catchment & proportion & 0.07 & 0.07 & 0.00 & 0.37 & Cfor \\
\hline & Herbaceous and shrubs in the catchment & proportion & 0.08 & 0.04 & 0.02 & 0.20 & Cher \\
\hline & Reforestation in the catchment & proportion & 0.04 & 0.07 & 0.00 & 0.37 & Cref \\
\hline & Pasture in the catchment & proportion & 0.39 & 0.25 & 0.00 & 0.86 & Cpas \\
\hline & Sugarcane in the catchment & proportion & 0.31 & 0.28 & 0.00 & 0.90 & Csug \\
\hline & Other categories in the catchment & proportion & 0.11 & 0.12 & 0.00 & 0.47 & Coth \\
\hline \multirow[t]{6}{*}{ Drainage network scale $(30 \mathrm{~m})$} & Native forest in the drainage network & proportion & 0.21 & 0.22 & 0.00 & 0.77 & Nfor \\
\hline & Herbaceous and shrub in the drainage network & proportion & 0.60 & 0.22 & 0.06 & 0.93 & Nher \\
\hline & Reforestation in the drainage network & proportion & 0.00 & 0.01 & 0.00 & 0.06 & Nref \\
\hline & Pasture in the drainage network & proportion & 0.12 & 0.09 & 0.00 & 0.43 & Npas \\
\hline & Sugarcane in the drainage network & proportion & 0.01 & 0.05 & 0.00 & 0.42 & Nsug \\
\hline & Other categories in the drainage network & proportion & 0.05 & 0.05 & 0.00 & 0.22 & Noth \\
\hline \multirow[t]{6}{*}{ Local scale (150 m radius circle) } & Native forest in the local area & proportion & 0.18 & 0.21 & 0.00 & 0.79 & Lfor \\
\hline & Herbaceous and shrub in the local area & proportion & 0.27 & 0.19 & 0.00 & 0.65 & Lher \\
\hline & Reforestation in the local area & proportion & 0.01 & 0.05 & 0.00 & 0.30 & Lref \\
\hline & Pasture in the local area & proportion & 0.32 & 0.24 & 0.00 & 0.92 & Lpas \\
\hline & Sugarcane in the local area & proportion & 0.14 & 0.20 & 0.00 & 0.68 & Lsug \\
\hline & Other categories in the local area & proportion & 0.07 & 0.09 & 0.00 & 0.44 & Loth \\
\hline \multirow[t]{4}{*}{ Natural landscape variables } & Catchment area & $\mathrm{km}^{2}$ & 6.67 & 5.55 & 0.90 & 32.96 & area \\
\hline & Average slope of the catchment & percentage & 9.94 & 1.67 & 6.98 & 14.09 & slo \\
\hline & Altitude & $\mathrm{m}$ & 458.64 & 49.09 & 360 & 619 & alt \\
\hline & Stream order & Strahler number & 2.05 & 0.57 & 1 & 4 & ord \\
\hline Category & Response Variables & Unit & & & & & Code \\
\hline \multirow[t]{3}{*}{ Substrate } & Sand & proportion & 0.46 & 0.26 & 0.00 & 1 & san \\
\hline & Consolidated substrate: bedrock, gravel and boulders & proportion & 0.14 & 0.19 & 0.00 & 0.85 & Csub \\
\hline & Unconsolidated substrate: mud and/or silt & proportion & 0.22 & 0.21 & 0.00 & 0.90 & Usub \\
\hline \multirow[t]{2}{*}{ Instream cover } & Leaf litter & proportion & 0.13 & 0.14 & 0.00 & 0.70 & litt \\
\hline & Small and large woody debris & proportion & 0.04 & 0.07 & 0.00 & 0.30 & wood \\
\hline \multirow[t]{6}{*}{ Marginal and riparian vegetation } & Grasses (mostly weed Brachiaria spp.) & proportion & 0.37 & 0.31 & 0.00 & 1 & gras \\
\hline & Bryophytes and Pteridophytes & proportion & 0.07 & 0.08 & 0.00 & 0.40 & bryo \\
\hline & Fine roots & proportion & 0.11 & 0.14 & 0.00 & 0.65 & Froot \\
\hline & Large roots & proportion & 0.03 & 0.06 & 0.00 & 0.30 & Lroot \\
\hline & Shrubs & proportion & 0.10 & 0.13 & 0.00 & 0.60 & $\operatorname{shr}$ \\
\hline & Exposed streambank & proportion & 0.30 & 0.25 & 0.00 & 0.85 & exb \\
\hline \multirow[t]{3}{*}{ Mesohabitats } & Pools & proportion & 0.20 & 0.14 & 0.00 & 0.60 & pool \\
\hline & Riffles & proportion & 0.72 & 0.19 & 0.30 & 1 & rif \\
\hline & Runs & proportion & 0.08 & 0.11 & 0.00 & 0.45 & run \\
\hline Stream physical habitat condition & Physical Habitat Index (PHI) & absolute value & 80.9 & 34.7 & 8 & 151 & phi \\
\hline \multirow[t]{6}{*}{ Stream morphology } & Mean width & $\mathrm{m}$ & 1.65 & 0.68 & 0.41 & 3.28 & wid \\
\hline & Standard deviation of mean width & - & - & - & 0.00 & 2.07 & widSD \\
\hline & Mean depth & $\mathrm{m}$ & 0.19 & 0.09 & 0.05 & 0.50 & dep \\
\hline & Standard deviation of mean depth & - & - & - & 0.03 & 0.37 & depSD \\
\hline & Mean water velocity & $\mathrm{m} / \mathrm{s}$ & 0.12 & 0.07 & 0.01 & 0.32 & vel \\
\hline & Standard deviation of mean water velocity & - & - & - & 0.00 & 0.23 & velSD \\
\hline \multirow[t]{4}{*}{ Physicochemical water properties } & Conductivity & $\mathrm{mS} / \mathrm{cm}$ & 89.86 & 46.68 & 19 & 277 & con \\
\hline & $\mathrm{pH}$ & - & 7.22 & 0.36 & 6.37 & 8.12 & $\mathrm{pH}$ \\
\hline & Total dissolved solids (TDS) & $\mathrm{g} / \mathrm{L}$ & 0.06 & 0.03 & 0.01 & 0.20 & tds \\
\hline & Water temperature & ${ }^{\circ} \mathrm{C}$ & 20.19 & 3.06 & 13.72 & 32.11 & tem \\
\hline
\end{tabular}

possible and to reduce the effects of outliers (Legendre and Legendre, 2012). Thereby, for the response and explanatory variables that were obtained as proportions, we used logit transformation (Warton and Hui, 2011). For the other variables, we used the natural logarithm transformation because it is more appropriate for data that depart broadly from the normal distribution (Legendre and Legendre, 2012). Finally, because our response variables were not dimensionally homogeneous (i.e., they were a combination of proportions, measures, concentrations, and other units), we standardized them to zero mean and unit variance for the following analyses (Legendre and Legendre, 2012). We used 10,000 permutations $(p<0.05)$ to test the significance of $(1)$ the relationships between instream variables, land use at different spatial scales and the natural landscape variables and (2) individual canonical axes in the RDA (Oksanen et al., 2015).
To identify the effect of the catchment, the drainage network, local land use and the natural landscape variables on instream features, we run a partial redundancy analysis (p-RDA). The p-RDA identifies the partial contribution of one set of explanatory variables when controlling the effect of another set (Legendre and Legendre, 2012). Thereby, p-RDA allows the partitioning of response variables variance into fractions explained by each set of explanatory variables (Legendre et al., 2011). We used 10,000 permutations $(p<0.05)$ to test the partial contribution of each set of explanatory variables. To conduct the variance inflation factor and the p-RDA and the RDA analyses, we used the 'vegan' (Oksanen et al., 2015) and 'car' packages, respectively. All analyses were carried out in the $\mathrm{R}$ environment ( $\mathrm{R}$ Development Core Team, 2014). 


\section{Results}

We found a strong positive correlation between the proportion of forests at the catchment and network scales $(r=0.70)$. We identified a similar pattern for pasture and sugarcane uses, with a higher correlation between the catchment and local scales $(r>0.6)$ (Table S1). Forest at the catchment and the network was negatively correlated to herbaceous vegetation at the network $(r=-0.55$ and -0.82). Sugarcane and pasture at the catchment were positively $(r=0.38)$ and negatively ( $\mathrm{r}=-0.39$ ) correlated to forest at the network, respectively (Table S1).

Variance partitioning based on p-RDA showed that land use at the catchment scale was the most important set of variables for explaining instream variation (pure effect $=6.4 \% ; p=0.001$ ), followed by local (pure effect $=6.1 \% ; p=0.001$ ) and network (pure effect $=2.3 \%$; $p=0.032$ ). The natural landscape variables set was not significant $(p=0.06)$. Approximately $80 \%$ of all instream variation remained unexplained by the predictor variables.

Since p-RDA indicated that natural landscape variables were not significant, we do not consider this set of variables to perform the RDA. The RDA results showed that land use at different scales influenced instream variables $\left(\mathrm{R}_{\text {adj }}^{2}=0.17 ; \mathrm{R}^{2}=0.33 ; p=0.001\right)$. The first six axes were significant $(p \leq 0.038)$. However, since the first two axes explained the highest proportion of the variation $\left(R^{2}=0.18\right)$, we retained only these to explore the relationship between land use and instream habitat. The first axis distinguished homogeneous (negative side) from heterogeneous streams (positive side). Homogeneous streams showed a higher proportion of marginal grasses and sandy substrate. At the local scale, homogeneous streams were associated with the proportion of herbaceous and shrubs vegetation (Lher), other land uses (Loth) and pasture (Lpas). At the drainage network scale, they were associated with other uses (Noth) and pasture (Npas). At the catchment scale, pasture (Cpas) and other uses (Coth) were associated with instream homogeneous condition (Fig. 3A and B).

Conversely, heterogeneous streams exhibited higher PHI values (Physical Habitat Index), a greater proportion of bryophytes and pteridophytes (bryo), small and large woody debris on the stream channel (wood), large (Lroot) and fine (Froot) roots and leaf litter (litt). Moreover, these streams have a higher proportion of pools and runs, a higher presence of shrubs in the riparian area and higher mean values of channel width. At the local and catchment scales, heterogeneous streams were associated with the proportion of native forest (Lfor, Cfor) and sugarcane (Lsug, Csug) (Fig. 3A and B). At network scale, these streams were associated with reforestation (Nref).

In the second axis, we observed a gradient related to the physicochemical variables and stream morphology. The first clustering (positive side) showed streams with higher conductivity, total dissolved solids, $\mathrm{pH}$ and water temperature associated with pasture at the local, network and catchment scales, in addition to other uses at the network and herbaceous and shrubs vegetation and other land uses at the catchment scale. The negative side showed streams with higher mean values of water velocity and depth associated with sugarcane at the local and catchment scales (Fig. 3A and B).

Furthermore, we observed a higher number of streams with poor structural and physicochemical integrity. These streams were associated with agricultural land uses at all spatial scales, especially pasture and others uses, which include some perennial and annual plants for agricultural purposes (Citrus spp., Coffea spp., Zea mays, and Sorghum bicolor) (Fig. 3B). However, we observed fewer streams with higher physical heterogeneity, depth, width and water velocity mainly associated with native forest and sugarcane (Fig. 3B).

\section{Discussion}

Land use at different spatial scales influenced instream habitat features. Natural landscape variables (catchment area, average slope,
A

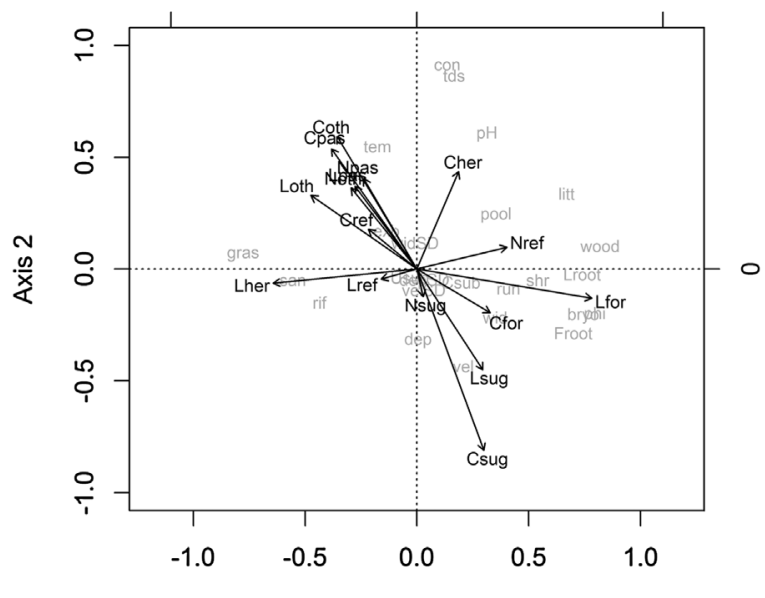

Axis 1

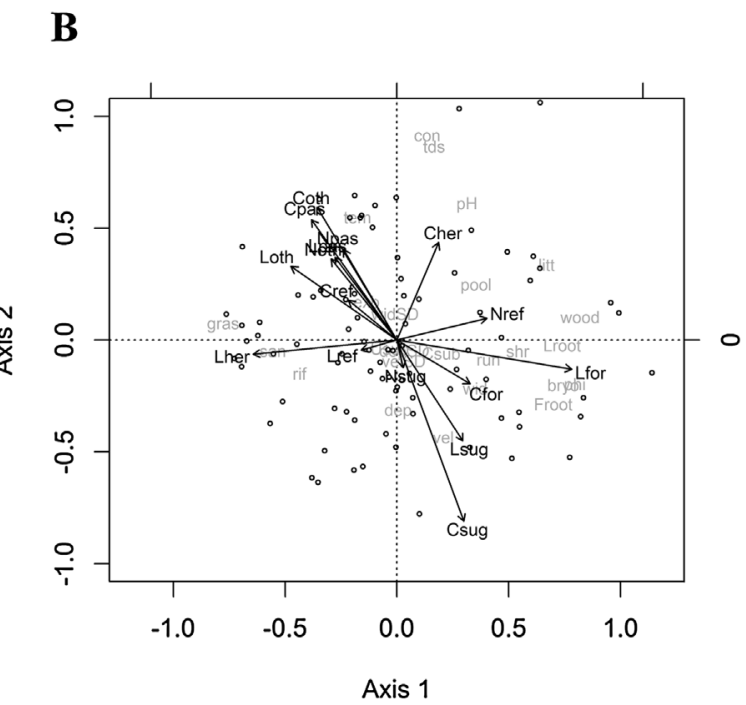

Fig. 3. (A) Relationship between land use at the catchment, network and local scales and instream variables. (B) Relationship between land use at the catchment, network and local scales and instream variables and distribution of the 86 sampling sites, represented by points. For variables' codes, see Table 2 .

altitude, and stream order) did not influence instream variables. Although some studies have found that natural landscape variables are important predictors of abiotic (Leal et al., 2016) and biotic (Wang et al., 2003) features of streams, we attributed its non-significance to the fact that these variables were controlled by our sampling design and that all sites were located in a geomorphologically similar region. Despite the well-established relationship between land use and instream habitat (Allan, 2004; Paula et al., 2013), we found a weak relationship between land use and instream variables in this region (i.e., $20 \%$ explained variation), probably as a result of the deep and intense humaninduced changes that have occurred since the beginning of the $20^{\text {th }}$ century. In this context, land use at the catchment and local scales were the most important variables for explaining instream habitat variation, whereas the influence of land use at the network scale was weak. In general, land use at the catchment scale affected physicochemical water properties and stream morphology, whereas stream physical habitat was mainly influenced by land use at the local scale. Moreover, agricultural uses can influence instream features differently because pasture and other uses were associated with homogeneous instream condition and sugarcane with heterogeneous. Interestingly, while sugarcane at the catchment scale was positively correlated with forest networks, pasture was negatively correlated with forests at this scale. 
The homogeneous physical condition was characterized by a high proportion of marginal grasses and sandy substrate, which are instream variables associated with a decrease of native forest and an increase of herbaceous (mainly Typha spp.) and shrubs vegetation at the local scale. Previous studies have associated grass invasion and siltation with low physical habitat heterogeneity (Casatti et al., 2012; Heino, 2013; Zeni and Casatti, 2014). When riparian forests are lacking, an increase in solar radiation provides a suitable environment for the establishment of invasive weeds, such as Brachiaria spp. (Bunn et al., 1998). Invasive weeds such as these can be significantly reduced under shadow, which is clearly promoted by riparian forests (Ceneviva-Bastos and Casatti, 2014; Evangelista et al., 2017). Moreover, the long time since the deforestation started (approximately 100 years; Monbeig, 1998), the intensive agricultural practices and the high erosive potential (Silva et al., 2007) in this region contribute to high inputs of inorganic sediments that gradually increase siltation (Rebouças et al., 2006). During an experimental manipulation in streams in the same region for 21 months, Ceneviva-Bastos and Casatti (2014) verified a marked increase in siltation. In this context, the removal of local native forest is decisive for the establishment of invasive marginal grasses and siltation, with both processes responding to homogenization in agricultural streams.

Considering that all of the streams are from the same geomorphological unit (IPT, 1999), physicochemical features are a consequence of different land uses and not different soil constitution. For instance, higher conductivity, TDS, $\mathrm{pH}$ and water temperature were mainly associated with pasture, other land uses, herbaceous and shrubs vegetation in the catchment. The management practices used in pastures and perennial agricultural lands (other land uses) likely contributed to the increase of the ions and the decrease of the water quality in these streams. In pasture catchments, cattle normally have free access to streams for watering, which can increase the total dissolved solids and conductivity due to the constant disturbance and re-suspension of stream banks and substrate (Roche et al., 2013 and references therein, but see Gary et al., 1983). Moreover, the increase of TDS, in addition to conductivity and $\mathrm{pH}$, could be related to organic residuals originating from cattle grazing (Roche et al., 2013; and see Gary et al., 1983). In contrast, perennial and annual crops (other land uses) use high amounts of fertilizer and pesticides (Martinelli et al., 2010; FAOSTAT, 2016), which interfere with water quality properties (Peterson et al., 2011; Sheldon et al., 2012). Due to the high solubility of these physicochemical variables, they are more prone to respond to large spatial scales than to local ones (Peterson et al., 2011; Sheldon et al., 2012). Although the riparian forest benefits from buffering agricultural impacts, most of these streams have their forests in a much degraded condition. Indeed, in the 86 studied catchments, on average, $60 \%$ of the 30 -m buffer zone along the drainage network corresponded to areas occupied by herbaceous and shrub vegetation and $12 \%$ by pasture for livestock (unpublished data). This result has important implications not only for stream conservation but also for the water treatment and supply, especially because the region is critical regarding surface water availability (SSRH/CRHi, 2009).

Heterogeneous physical condition was mainly determined by the presence of forest at local scale. Streams with more proportion of local forest showed marginal vegetation and instream habitat more diversified with high physical habitat indexes. The presence of forested buffer along the streamside has been noted as one of the best predictors for the instream habitat condition (Casatti et al., 2015; Leal et al., 2016). The input of allochthonous material, as wood debris, for example, can promote changes in water velocity and create different mesohabitats (Paula et al., 2011), thereby increasing channel structure variability (i.e., higher PHI values; Casatti et al., 2006).

Interestingly, some of these heterogeneous streams were also associated with sugarcane at the catchment scale. Over the last few decades, São Paulo state has shown a massive expansion of sugarcane crops (Lapola et al., 2014). Although there is concern about the effects of sugarcane on native forests (Arthington et al., 1997; Lapola et al.,
2010), in São Paulo most of the land-use change associated with sugarcane crops has occurred in preexisting agricultural watersheds (i.e., pastures conversion to sugarcane) (Adami et al., 2012; Lapola et al., 2014). Due to international pressures, sugarcane industries tries to comply with Brazilian environmental law (e.g., stream buffers; UNICA, 2016), and stream buffers are usually isolated for natural regeneration. Through time, this practice can lead to riparian regeneration (Ferraz et al., 2014). In fact, during our fieldwork, we observed a higher occurrence of forest buffers in sugarcane crops than in pastures. The correlation is indeed weak, but the catchments dominated by sugarcane had different times of pasture conversion and, probably, different forest restoration stages. It is possible that by maintaining this environmental accordance policy, the correlation between sugarcane at catchment and forest at network drainage will increase over time.

Furthermore, we found that land use was usually consistent at all three scales (for some cases, the correlation was not very strong). These results may indicate two important findings: (1) most of the few native forest remains are concentrated in the riparian area, and (2) when catchments dominated by agricultural crops (pasture and sugarcane) show any riparian forest, these are smaller than $30 \mathrm{~m}$. Despite the weak positive correlation between sugarcane at the catchment and forest at the network scale (mentioned above), we must say that conservation and restoration of the riparian forests in these agricultural catchments are far from what is determined by the Brazilian Forest Code and are even more distant from what recent studies have proposed as the minimum width for maintaining the integrity of physical habitat, communities and ecosystems functions. Sweeney and Newbold (2014) have estimated that for small streams ( $\leq 5^{\text {th }}$-order according to Strahler method), forested buffers $\geq 30 \mathrm{~m}$ wide are needed to protect their physical, chemical, and biological integrity. However, contrary to several scientific studies (e.g., Metzger et al., 2010; Sparovek et al., 2012; Soares-Filho et al., 2014), the most recent Forest Code (Law 12.651/12) made the minimum width for the streamside protected buffer more flexible ("Area de Proteção Permanente", APP, in Portuguese). As the main criteria for that change, the Forest Code establishes the minimum protected buffer width according to the fiscal module (a type of agrarian measurement, which is variable according to the municipality's location). Although our study did not intend to identify compliance with environmental law or to test the effectiveness of the $30-\mathrm{m}$ width of forested buffers to maintain stream integrity, we can state that the current riparian forest condition in the studied basins is not appropriate for maintaining neither the habitat integrity nor aquatic ecosystem functions.

The absence of riparian forests along stream buffer networks is probably the cause of the relative low influence of the network scale on instream features (p-RDA results). In this scenario, it is possible to hypothesize the loss or the drastic reduction of the functions provided by the riparian forests (e.g., channel structuring, bank stability, agrochemical filtering, shading, or the input of allochthonous material; Sweeney et al., 2004). Perhaps the simple explanation of catchment and local land uses are related to their influences on water quality and physical habitats, respectively (as discussed above). However, most of the instream variance remains unexplained by our variables. Several factors likely underline this result. According to Leal et al. (2016), multiple explanatory descriptors can be responsible for instream habitat features, and it is difficult to find patterns, especially when landscape history is not considered. In fact, in a recent study in the same area, Roa-Fuentes and Casatti (2017) affirmed that historic human-induced changes in this area can probably weaken the relationship between current land use and fish assemblages. According to some authors, this relationship between landscape and fish assemblages is indirect and is mediated by instream feature changes (e.g., Iwata et al., 2003; Smokorowski and Pratt, 2007; Pease et al., 2011). If we consider this factor, it is possible that the findings of Roa-Fuentes and Casatti (2017) are mediated by the weakening relationship between landscape features and instream habitat features, as demonstrated in the present study. 
Moreover, recent pasture conversion to sugarcane in the area may have affected the relationship between landscape and instream habitat at all scales. There is evidence of legacy effects in the streams from our region (J. O. Zeni, pers. obs.) because the current instream physical structure was more associated with past land use. Thus, the instream habitat changes may not have followed the same rate of the landscape changes and more time is necessary for instream habitat to adjust to the current land use.

Our study demonstrated that different scales and land uses affected the instream features. The local scale was more related to physical habitat, while the catchment scale was more related to water quality. Pasture, herbaceous, and other land uses were associated with homogeneous streams; whereas forest and sugarcane were associated with heterogeneous streams. Moreover, sugarcane catchments showed a positive correlation with forests at the network scale, perhaps evidencing initial riparian forest regeneration. However, the amount and quality of riparian forest are apparently insufficient to buffer the impacts from our highly modified landscape. Finally, our results can provide an important tool to suggest effective management and restoration practices since multiple scales can influence the integrity of instream habitat and water quality.

\section{Acknowledgments}

We are grateful to Erick Manzano, Ana Claúdia dos Santos, Angelo R. Manzotti, Marina Reghini, Gabriel L. Brejão and Mrs. Paulo Maiorano for help during fieldwork; to Frederico S. Miranda, Márcia S. Morinaga and Silvio F. B. Ferraz (ESALQ/SP) for help with ArcGis analysis; to Maria Stela M. C. Noll and Luís H. Z. Branco for suggestions to the first draft of this manuscript; and to Fundação de Amparo à Pesquisa do Estado de São Paulo (FAPESP) for financial support (2012/ 05983-0). MCM is financially supported by CAPES/MEC (Coordenação de Aperfeiçoamento de Pessoal de Nível Superior do Ministério da Educação); CARF received a scholarship from the TWAS-CNPq Postgraduate Fellowship Program (190199/2011-3); JOZ was financially supported by FAPESP (2012/20280-5); LC receives a grant from CNPq (301755/2013-2).

\section{Appendix A. Supplementary data}

Supplementary data associated with this article can be found, in the online version, at http://dx.doi.org/10.1016/j.limno.2017.06.001.

\section{References}

Adami, M., Rudorff, B.F.T., Freitas, R.M., Aguiar, D.A., Sugawara, L.M., Mello, M.P., 2012. Remote sensing time series to evaluate direct land use change of recent expanded sugarcane crop in Brazil. Sustainability 4, 574-585. http://dx.doi.org/10. 3390/su4040574.

Allan, J.D., 2004. Landscapes and riverscapes: the influence of land use on stream ecosystems. Annu. Rev. Ecol. Evol. Syst. 35, 257-284. http://dx.doi.org/10.1146/ annurev.ecolsys.35.120202.110122.

Arthington, A.H., Marshal, J.C., Rayment, G.E., Hunter, H.M., Bunn, S.E., 1997. Potential impact of sugarcane production on riparian and freshwater environments. In: Keating, B.A., Wilson, J.R. (Eds.), Intensive Sugarcane Production: Meeting the Challenges Beyond 2000. CAB International, Wallingford, Oxfordshire, pp. 403-412.

Bu, H., Meng, W., Zhang, Y., Wan, J., 2014. Relationships between land use patterns and water quality in the Taizi River basin, China. Ecol. Indic. 41, 187-197. http://dx.doi. org/10.1016/j.ecolind.2014.02.003.

Bunn, S.E., Davies, P.M., Kellaway, D.M., Prosser, I.P., 1998. Influence of invasive macrophytes on channel morphology and hydrology in an open tropical lowland stream, and potential control by riparian shading. Freshwater Biol. 39, 171-178. http://dx. doi.org/10.1046/j.1365-2427.1998.00264.x.

Burnett, K.M., Reeves, G.H., Clarke, S.E., Christiansen, K.R., 2006. Comparing riparian and catchment influences on stream habitat in a forested montane landscape. Am. Fish. Soc. Symp. 48, 175-197.

Casatti, L., Langeani, F., Silva, A.M., Castro, R.M.C., 2006. Stream fish, water and habitat quality in a pasture dominated basin, southeastern Brazil. Braz. J. Biol. 66, 681-696. http://dx.doi.org/10.1590/S1519-69842006000400012.

Casatti, L., Teresa, F.B., Gonçalves-Souza, T., Bessa, E., Manzotti, A.R., Gonçalves, C.S., Zeni, J.O., 2012. From forests to cattail: how does the riparian zone influence stream fish? Neotropical Ichthyol. 10, 205-214. http://dx.doi.org/10.1590/S1679-
62252012000100020.

Casatti, L., Teresa, F.B., Zeni, J.O., Ribeiro, M.D., Brejão, G.L., Ceneviva-Bastos, M., 2015. More of the same: high functional redundancy in stream fish assemblages from tropical agroecosystems. Environ. Manage. 55, 1300-1314. http://dx.doi.org/10.1007/ s00267-015-0461-9.

Ceneviva-Bastos, M., Casatti, L., 2014. Shading effects on community composition and food web structure of a deforested pasture stream: evidences from a field experiment in Brazil. Limnologica 46, 9-21. http://dx.doi.org/10.1016/j.limno.2013.11.005.

Clapcott, J.E., Collier, K.J., Death, R.G., Goodwin, E.O., Harding, J.S., Kelly, D., Leathwick, J.R., Young, R.G., 2012. Quantifying relationships between land-use gradients and structural and functional indicators of stream ecological integrity. Freshwater Biol. 57, 74-90. http://dx.doi.org/10.1111/j.1365-2427.2011.02696.x.

Dala-Corte, R.B., Giam, X., Olden, J.D., Becker, F.G., Guimarães, T.F., Melo, A.S., 2016. Revealing the pathways by which agricultural land-use affects stream fish communities in South Brazilian grasslands. Freshwater Biol. 61, 1921-1934. http://dx.doi. org $/ 10.1111 /$ fwb. 12825 .

Evangelista, H.B., Michelan, T.S., Gomes, L.C., Thomaz, S.M., 2017. Shade provided by riparian plants and biotic resistance by macrophytes reduce the establishment of an invasive Poaceae. J. Appl. Ecol. 54, 648-656. http://dx.doi.org/10.1111/1365-2664. 12791.

FAOSTAT, 2016. The Statistics Division of FAO. http://faostat3. fao.org/(accessed 13. 06.16)

Fausch, K.D., Torgersen, C.E., Baxter, C.D., Li, H.W., 2002. Landscapes to riverscapes: bridging the gap between research and conservation of stream fishes. Bioscience 52, 483-498. http://dx.doi.org/10.1641/0006-3568(2002)052[0483:LTRBTG]2.0.CO;2.

Feld, C.K., 2013. Response of three lotic assemblages to riparian and catchment-scale land use: implications for designing catchment monitoring programmes. Freshwater Biology 58, 715-729. http://dx.doi.org/10.1111/fwb.12077.

Ferraz, S.F.B., Ferraz, K.M.P.M.B., Cassiano, C.C., Brancalion, P.H.S., Luz, D.T.A., Azevedo, T.N., Tambosi, L.R., Metzger, J.P., 2014. How good are tropical forest patches for ecosystem services provisioning? Landscape Ecol. 29, 187-200. http://dx. doi.org/10.1007/s10980-014-9988-Z.

Gary, H.L., Johnson, S.R., Ponce, S.L., 1983. Cattle grazing impact on surface water quality in a Colorado front range stream. J. Soil Water Conserv. 38, 124-128.

Heino, J., 2013. Environmental heterogeneity, dispersal mode, and co-occurrence in stream macroinvertebrates. Ecol. Evol. 3, 344-355. http://dx.doi.org/10.1002/ece3. 470.

Hynes, H.B.N., 1975. The stream and its valley. Verhandlungen der Internationalen Vereinigung für Theoretische und Angewandte Limnologie 19, 1-15.

IPT (Instituto de Pesquisas Tecnológicas do Estado de São Paulo), 1999. Diagnóstico Da Situação Atual Dos Recursos Hídricos E Estabelecimento De Diretrizes técnicas Para a Elaboração Do Plano Da Bacia Hidrográfica Do Turvo/Grande - Relatório 40.515. Secretaria De Recursos Hídricos. Saneamento e Obras, São Paulo.

Iwata, T., Nakano, S., Inoue, M., 2003. Impacts of past riparian deforestation on stream communities in a tropical rain forest in Borneo. Ecol. Appl. 13, 461-473.

Lapola, D.M., Schaldach, R., Alcamo, J., Bondeau, A., Koch, J., Koelking, C., Priess, J.A., 2010. Indirect land-use changes can overcome carbon savings from biofuels in Brazil. Proc. Natl. Acad. Sci. 107, 3388-3393. http://dx.doi.org/10.1073/pnas. 0907318107.

Lapola, D.M., Martinelli, L.A., Peres, C.A., Ometto, J.P.H.B., Fereira, M.E., Nobre, C.A., Aguiar, A.P.D., Bustamante, M.M.C., Cardoso, M.F., Costa, M.H., Joly, C.A., Leite, C.C., Moutinho, P., Sampaio, G., Strassburg, B.N.N., Vieira, I.C., 2014. Pervasive transition of the Brazilian land-use system. Nat. Clim. Change 4, 27-35. http://dx. doi.org/10.1038/nclimate2056.

Leal, C.G., Pompeu, P.S., Gardner, T.A., Leitão, R.P., Hughes, R.M., Kaufmann, P.R., Zuanon, J., Paula, F.R., Ferraz, S.F.B., Thomson, J.R., 2016. Multi-scale assessment of human-induced changes to Amazonian instream habitats. Landscape Ecol. 31, 1725-1745. http://dx.doi.org/10.1007/s10980-016-0358-x.

Legendre, P., Legendre, L., 2012. Numerical Ecology, 3rd edition. Elsevier, Amsterdam.

Legendre, P., Oksanen, J., ter Braak, C.J.F., 2011. Testing the significance of canonical axes in redundancy analysis. Methods Ecol. Evol. 2, 269-277. http://dx.doi.org/10. 1111/j.2041-210X.2010.00078.x.

Martinelli, L.A., Filoso, S., 2008. Expansion of sugarcane ethanol production in Brazil: environmental and social challenges. Ecol. Appl. 18, 885-898. http://dx.doi.org/10. 1890/07-1813.1.

Martinelli, L.A., Naylor, R., Vitousek, P.M., Moutinho, P., 2010. Agriculture in Brazil: impacts, costs and opportunities for a sustainable future. Curr. Opin. Environ. Sustain. 2, 431-438. http://dx.doi.org/10.1016/j.cosust.2010.09.008.

Metzger, J.L., Lewinsohn, T.M., Joly, C.A., Verdade, L.M., Martinelli, L.A., Rodigues, R.R., 2010. Brazilian law: full speed in reverse? Science 329, 276-277. http://dx.doi.org/ 10.1126/science.329.5989.276-b.

Monbeig, P., 1998. Pioneiros e fazendeiros de São Paulo. Hucitec Polis, São Paulo.

Mori, G.B., de Paula, F.R., de Barros Ferraz, S.F., Camargo, A.F.M., Martinelli, L.A., 2015. Influence of landscape properties on stream water quality in agricultural catchments in Southeastern Brazil. Annales de Limnologie - Int. J. Limnol. 51, 11-21. http://dx. doi.org/10.1051/limn/2014029.

Nalon, M.A., Mattos, I.F.A., Franco, G.A.D.C., 2008. Meio físico e aspectos da fragmentação da vegetação. In: Rodrigues, R.R., Bononi, V.L.R. (Eds.), Diretrizes Para a Conservação e Restauração da Biodiversidade no Estado de São Paulo. Secretaria do Meio Ambiente e Instituto de Botânica, São Paulo, pp. 17-21.

Neter, J., Kutner, M., Nachtsheim, C., Wasserman, W., 1996. Applied Linear Statistical Models. McGraw-Hill Companies, Inc., NY.

Oksanen, J., Blanchet, F.G., Kindt, R., Legendre, P., Minchin, P.R., O'Hara, R.B., Simpson, G.L., Solymos, P., Henry, M., Stevens, H., Wagner, H., 2015. Vegan: Community Ecology Package. R Package Version 2. 2-1. http://CRAN.R-project.org/package $=$ vegan $($ accessed 28.11.16) 
Paula, F.R., Ferraz, S.F.B., Gerhard, P., Vettorazzi, C.A., Ferreira, A., 2011. Large woody debris input and its influence on channel structure in agricultural lands of Southeast Brazil. Environ. Manage. 48, 750-763. http://dx.doi.org/10.1007/s00267-0119730-4.

Paula, F.R., Gerhard, P., Wenger, S.J., Ferreira, A., Vettorazzi, C.A., Ferraz, S.F.B., 2013. Influence of forest cover on in-stream large wood in an agricultural landscape of southeastern Brazil: a multi-scale analysis. Landscape Ecol. 28, 13-27. http://dx.doi. org/10.1007/s10980-012-9809-1.

Pease, A.A., Taylor, J.M., Winemiller, K.O., King, R.S., 2011. Multiscale environmental influences on fish assemblage structure in Central Texas streams. Trans. Am. Fish. Soc. 140, 1409-1427. http://dx.doi.org/10.1080/00028487.2011.623994.

Peterson, E.E., Sheldon, F., Darnell, R., Bunn, S.E., Harch, B.D., 2011. A comparison of spatially explicit landscape representation methods and their relationship to stream condition. Freshwater Biol. 56, 590-610. http://dx.doi.org/10.1111/j.1365-2427. 2010.02507.x.

Pusey, B.J., Arthington, A.H., 2003. Importance of riparian zone to the conservation and management of freshwater fishes: a review. Mar. Freshwater Res. 54, 1-16. http://dx. doi.org/10.1071/MF02041.

R Development Core Team, 2014. R: A Language and Environment for Statistical Computing. R Foundation for Statistical Computing, Viena, Austria.

Rasmussen, J.J., Baattrup-Pedersen, A., Larsen, S.E., Kronvang, B., 2011. Local physical habitat quality cloud the effect of predicted pesticide runoff from agricultural land in Danish streams. J. Environ. Monit. 13, 943-950. http://dx.doi.org/10.1039/ c0em00745e.

Rebouças, A.C., Braga, B., Tundisi, J.G., 2006. Águas doces no Brasil: capital ecológico. uso e conservaçãoEscrituras, São Paulo.

Roa-Fuentes, C.A., Casatti, L., 2017. Influence of environmental features at multiple scales and spatial structure on stream fish communities in a tropical agricultural region. J. Freshwater Ecol. 32, 273-287. http://dx.doi.org/10.1080/02705060.2017.1287129.

Roche, L.M., Kromschroeder, L., Atwill, E.R., Dahlgren, R.A., Tate, K.W., 2013. Water quality conditions associated with cattle grazing and recreation on National forest lands. PLoS One 8, e68127. http://dx.doi.org/10.1371/journal.pone.0068127.

Rudorff, B.F.T., Aguiar, D.A., Silva, W.F., Sugawara, L.M., Adami, M., Moreira, M.A., 2010. Studies on the rapid expansion of sugarcane for ethanol production in São Paulo State (Brazil) using Landsat data. Remote Sens. 2, 1057-1076. http://dx.doi. org/10.3390/rs2041057.

SSRH/CRHi, 2009. Secretaria de Saneamento e Recursos Hídricos; Coordenadoria de Recursos Hídricos -2009. Relatório de Situação dos Recursos Hídricos do Estado de São Paulo, ano base 2007, São Paulo pp.146.

SWAT, 2009. Soil and Water Assessment Tool: ArcSWAT. College Station, Tex.: Texas A \& M University. http://swat.tamu.edu/(accessed 28.09.16).

Sheldon, F., Peterson, E.E., Boone, E.L., Sippel, S., Bunn, S.E., Harch, B.D., 2012
Identifying the spatial scale of land use that most strongly influences overall river ecosystem health score. Ecol. Appl. 22, 2188-2203. http://dx.doi.org/10.1890/111792.1.

Silva, A.M., Casatti, L., Alvares, C.A., Leite, A.M., Martinelli, L.A., Durrant, S.F., 2007. Soil loss risk and habitat quality in some streams of a meso-scale river basin. Scientia Agricola 64, 336-343. http://dx.doi.org/10.1590/S0103-90162007000400004.

Smokorowski, K.E., Pratt, T.C., 2007. Effect of a change in physical structure and cover on fish and fish habitat in freshwater ecosystems - a review and meta-analysis. Environ. Rev. 15, 15-41. http://dx.doi.org/10.1139/a06-007.

Soares-Filho, B., Rajão, R., Macedo, M., Carneiro, A., Costa, W., Coe, M., Rodrigues, H., Alencar, A., 2014. Cracking Brazil's forest code. Science 344, 363-364. http://dx. doi. org/10.1126/science.1246663.

Sparovek, G., Berndes, G., Barretto, A.G.O.P., Klug, I.L.F., 2012. The revision of the Brazilian Forest Act: increase deforestation or a historic step towards balancing agricultural development and nature conservation? Environ. Sci. Policy 16, 65-72. http://dx.doi.org/10.1016/j.envsci.2011.10.008.

Strayer, R., Beighley, E., Thompson, L.C., 2003. Effects of land cover on stream ecosystems: roles of empirical models and scaling issues. Ecosystems 6, 407-423. http://dx. doi.org/10.1007/PL00021506.

Sweeney, B.W., Newbold, J.D., 2014. Streamside forest buffer width needed to protect stream water quality, habitat, and organisms: a literature review. J. Am. Water Resour. Assoc. 50, 560-584. http://dx.doi.org/10.1111/jawr.12203.

Sweeney, B.W., Bott, T.L., Jackson, J.K., Kaplan, L.A., Newbold, J.D., Standley, L.J., Hession, W.C., Horwitz, R.J., Colman, M.G., 2004. Riparian deforestation, stream narrowing, and loss of stream ecosystem services. Proc. Natl. Acad. Sci. U. S. A. 10, 14132-14137. http://dx.doi.org/10.1073/pnas.0405895101.

UNICA - Sugar cane industry union, 2016. Production and Use of Fuel Ethanol in Brazil: Answers to the Most Frequently Asked Questions. http://www.globalbioenergy.org/ bioenergyinfo/background/detail/fi/c/2801/ (accessed 27.07.16).

Wang, L., Lyons, J., Kanehl, P., Gatti, R., 1997. Influences of watershed land use on habitat quality and biotic integrity in Wisconsin streams. Fisheries 22, 6-12. http://dx doi.org/10.1577/1548-446(1997)022\%3C0006:IOWLUO\%3E2.0. CO;2.

Wang, L., Lyons, J., Rasmussen, P., Seelbach, P., Simon, T., Wiley, M., Kanehl, P., Baker, E., Niemela, S., Stewart, P.M., 2003. Watershed, reach, and riparian influences on stream fish assemblages in the Northern Lakes and Forest Ecoregion. Can. J. Fish. Aquat. Sci. 60, 491-504. http://dx.doi.org/10.1139/f03-043.

Warton, D.I., Hui, F.K.C., 2011. The arcsine is asinine: the analysis of proportions in ecology. Ecology 92, 3-10. http://dx.doi.org/10.1890/10-0340.1.

Zeni, J.O., Casatti, L., 2014. The influence of habitat homogenization on the trophic structure of fish fauna in tropical streams. Hydrobiologia 726, 259-270. http://dx. doi.org/10.1007/s10750-013-1772-6. 